\title{
Identification of Nano- and Microparticle Aerosols Generated in Selected Operations
}

\author{
Klouda Karel ${ }^{1}$, Sinay Juraj ${ }^{2 *}$, Cejpek Jiríi ${ }^{3}$, Lach Karel ${ }^{4}$ \\ 'State Office for Nuclear Safety, Senovážnénámëstí', Prague 1, (Zeech Republic \\ ${ }^{2}$ Technical University Kosice, Faculty of Mechanical Engineering, Slovak Republic \\ ${ }^{3}$ National Institute for Nuclear, Chemical and Biological Protection, Kamenná, Czech Republic \\ ${ }^{4}$ Institute of Public Health in Ostrava, Czech Republic
}

\section{BIOGRAPHICAL NOTES}

The authors are specialists in chemistry, nanoparticles, toxicity, safety of operations and occupational safety.

\section{KEY WORDS}

Aerosol, nanoparticle, shape and surface of nanoparticles, toxicity.

\begin{abstract}
The contribution presents results of measurements and evaluation of concentrations of nano- and microparticle aerosols in a joinery, metallurgical operation and uranium ore mine. The obtained results have been analyzed from the viewpoint of potential toxicity and in respect to the shape of nanoparticles. The contribution also presents results of tests of effectiveness of respirators as primary and basic personal protection equipment.
\end{abstract}

\section{Introduction}

Nanoparticles have been accompanying humankind since the time immemorial. They are generated during fires, volcano eruptions, as a result of erosion, chemical decomposition of organic matter and by anthropogenic activities, e.g. burning of fossil fuels (thermal power plants, combustion engines, etc.) and recently also engineered nanoparticles have been made in research laboratories and in industrial plants. Nanoparticles were used already in the past, despite the fact that their users were not familiar with their essential properties (in glassmaking, ceramics - glazes, chemical catalysis, metallurgy, production of soot, etc.) At present we would hardly find a field of human activity that does not use nanotechnologies and nanomaterials, including their use in many areas of everyday life.

After negative experience with some materials (e.g. DDT, PCB, dioxins etc.) the general public all over the world seeks to appeal to research centers and producers to observe the so-called precautionary principle also in case of nanomaterials and nanotechnologies.

When asking a question about what potential risks nanomaterials pose we can divide them into the following categories:

- risks for health (toxicity),

- risks for the environment (ecotoxicity),

- physicochemical risks, i.e. they may cause fire, explosion, uncontrolled and undesired reactions, 
- in the future it is impossible to exclude even nonethical uses of nanotechnologies and nanoparticles by third persons (criminal or terrorist acts, war conflict).

The first two potential risks are very closely connected as the very occurrence of nanoparticles in individual components of the environment enables their contact with living organisms.

In general, particle toxicity is influenced by a number of parameters including particle type, size, shape, concentration, distribution in the environment, water solubility, chemical reactivity, frequency and duration of exposure, interactions with other airborne chemicals, pulmonary ventilation and individual immunological condition [1-12].

The presence of nanoparticles in a living organism results in a number of interactions between their surfaces and biological systems. The interactions may lead to formation of protein coronas, wrapping of particles, intracellular absorption and biocatalytic processes, which may have both positive and negative results in terms of the toxicity. The organic world intertwines with the synthetic world of man-made nanomaterials. The nano-bio interfaces are created, associated with dynamic physicochemical interactions, kinetic and thermodynamic exchanges between surfaces of nanomaterials and surfaces of biological components (proteins, membranes, lipids, DNA, biological liquids etc.). A background research focusing on interaction at the nano-bio interface [13] has shown that only very little is known about what happens with nanoparticles inside a cell. Nanoparticles may cause a wide range of intracellular reactions which depend on their physicochemical properties, intracellular concentration, duration of contact etc. (see table 1)

In operations where nanoparticles are generated (particularly dust producing operations) the workers are mostly primarily endangered by inhalation of nanoparticles. The human respiratory tract consists of three sequential regions assisting the filtration effect, including nasopharyngeal, tracheobronchial and the pulmonary regions

The respiratory system can be considered a primary site of toxicity for the inhaled particles and, following absorption and depending on their physicochemical properties, a pathway for the inhaled chemicals (particles of a particular chemical composition) to reach other organs and tissues distant from the lung and elicit their toxic effects at extrapulmonary sites [15]

Nanomaterials have a superior potential to travel throughout the living organism compared to their corresponding conventional material at the larger scale.

Table 1: Nanomaterial characteristics and possible biological effects [14].

\begin{tabular}{|c|c|}
\hline $\begin{array}{l}\text { Nanomaterial } \\
\text { characteristics }\end{array}$ & Possible biological effects \\
\hline \multirow{5}{*}{$\begin{array}{l}\text { Small size distribution } \\
\text { (less than } 100 \mathrm{~nm} \text { ) }\end{array}$} & $\begin{array}{l}\text { Crossing tissue and cell } \\
\text { membranes }\end{array}$ \\
\hline & Cellular injury \\
\hline & $\begin{array}{l}\text { Phagocytosis impairment, } \\
\text { breakdown in defense me- } \\
\text { chanisms }\end{array}$ \\
\hline & Migration to other organs \\
\hline & $\begin{array}{l}\text { Transportation of other envi- } \\
\text { ronmental pollutants }\end{array}$ \\
\hline \multirow{2}{*}{$\begin{array}{l}\text { Large surface areal } \\
\text { mass ratio }\end{array}$} & Increased reactivity \\
\hline & Increased toxicity \\
\hline \multirow{8}{*}{ Surface characteristics } & ROS generation \\
\hline & Oxidative stress \\
\hline & Inflammation \\
\hline & Cytokine production \\
\hline & Glutathione depletion \\
\hline & Mitochondrial exhaustion \\
\hline & Cellular injury \\
\hline & Protein and DNA damage \\
\hline \multirow[t]{2}{*}{$\begin{array}{l}\text { Insolubility or low } \\
\text { water solubility }\end{array}$} & $\begin{array}{l}\text { Bioaccumulation inside living } \\
\text { systems such as human cells, } \\
\text { tissues and lungs }\end{array}$ \\
\hline & Potential long-term effects \\
\hline \multirow[t]{2}{*}{ Aggregation } & $\begin{array}{l}\text { Interruption of cellular pro- } \\
\text { cesses }\end{array}$ \\
\hline & Cellular injury \\
\hline
\end{tabular}

Responses to inhaled materials range from immediate reactions to long-term chronic adverse effects, from single tissue level to systemic diseases $[1,3]$. Large scale epidemiological studies have demonstrated that exposure to air pollution particles and ultrafine particles contribute significantly to increased respiratory and cardiovascular morbidity and mortality [16 - 20]. 
For the reasons indicated above we have already performed a number of measurements of distribution of nanoparticles in the course of anthropogenic activities, such as operation of the Prague subway, riding on a city bus, shooting, welding etc. [21].

The following contribution describes measurements of distribution of aerosol nano- and microparticles in dust producing operations, such as a
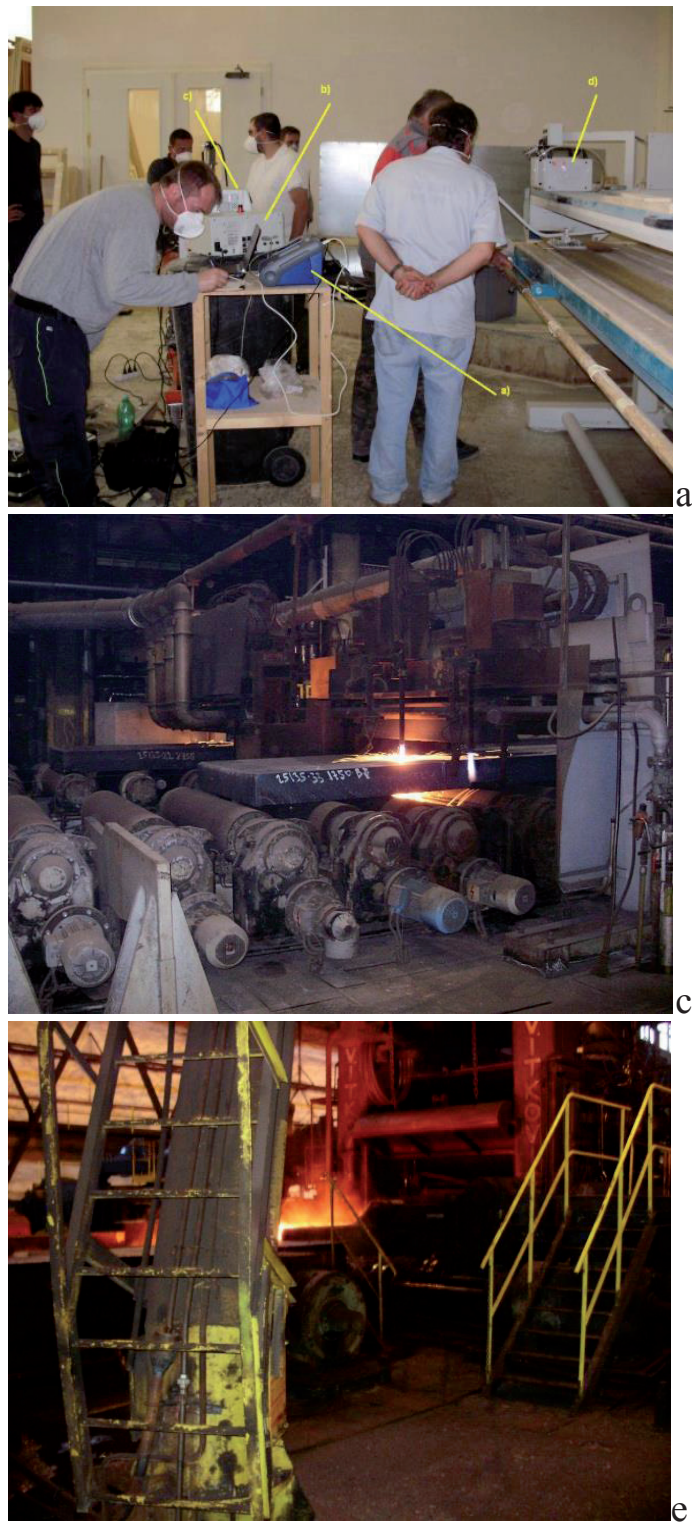

joinery, steelworks and steel rolling plant and mining of uranium ore in an underground mine. In the course of the measurements we also tested respirator efficiency and focused on shape of nano- and microparticles in the collected samples, which may influence the anticipated toxicity and ecotoxicity. The measuring points in dust producing operations are shown in Figure No. 1.
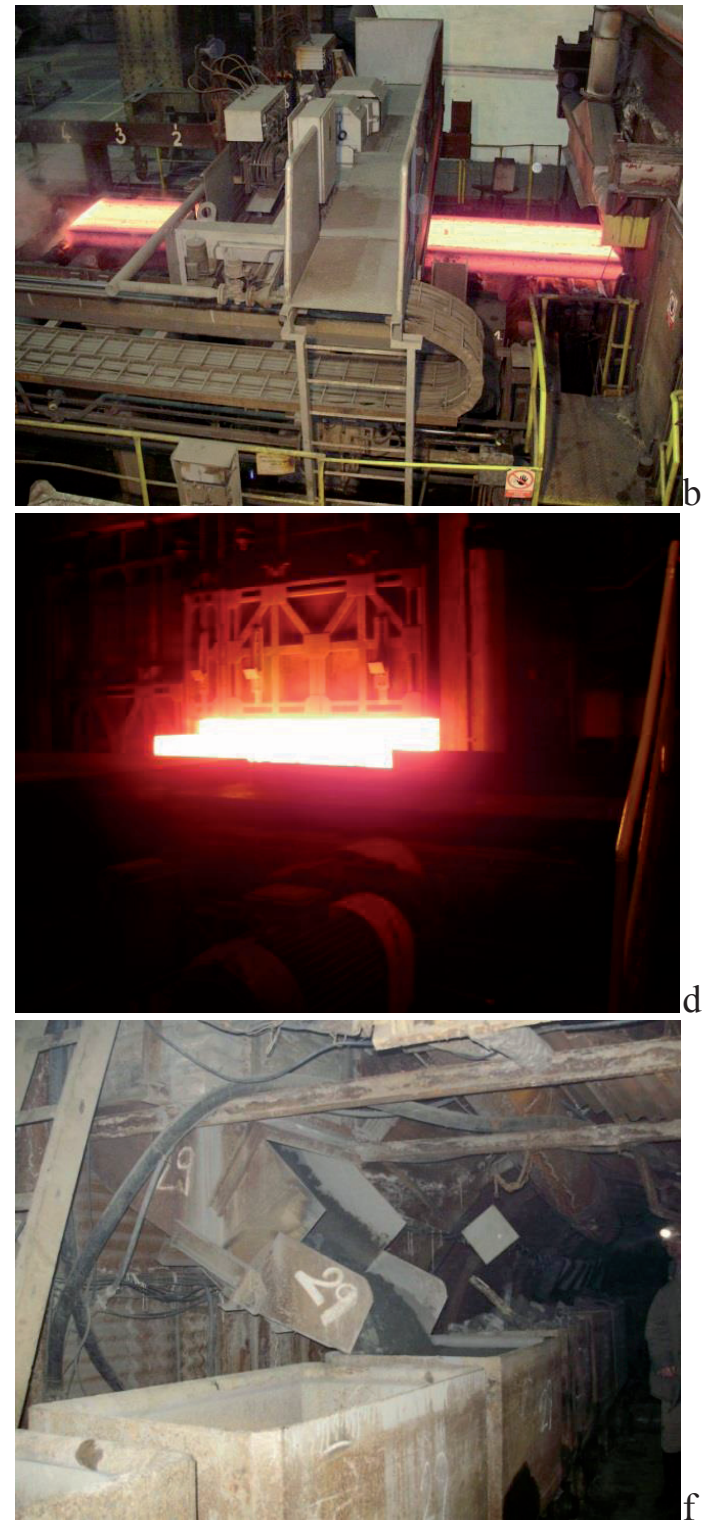

Fig. 1: Selected measuring points in operation with high exposure to dust: a) grinder with abrasive band, b) slab continual casting - steelworks, c) scarfing machine - steelworks, d) pusher furnace - steel rolling plant, e) rolling mill train, f) feeding of loose material into mine trucks. 


\section{Measuring Instruments}

The measurements of aerosol particles were conducted with SMPS (Scanning Mobility Particle Sizer) 3934 consisting of CPC (Condensation Particle Counter) 3022 (working in the low regime) and EC (Electrostatic Classifier) 3071 equipped with DMA (Differential Mobility Analyzer), probe 3081 and impactor $0.0457 \mathrm{~cm}$. The measurements were conducted using the setup scanning interval of 5 minutes, which enabled collection of samples in the range from $14 \mathrm{~nm}$ to $740 \mathrm{~nm}$.

Measurements of FIT factors of the protective respirators, device PortaCount Pro+ 8038 TSI, method MAZL - 40/11 (SÚJCHBO), OSHA 29CFR1910.134.

Weight capture of aerosol particles used Sioutas 225-370 cascade impactors. The personal cascade impactor consists of four impaction levels and an underlying filter that enables sorting and sampling of airborne particles in five size intervals. Samples were collected with the personal impactor which used the sampling device QuickTake30 at the constant flow rate 9 I. min $^{-1}$.

Evaluation of shape and size of nano- and microparticles collected in the individual operations was performed with electron microscope made by FEl, model Quanta 450 FEG, high fiber method, ETD detector (secondary electrons) and BSE (back-scattered electrons).

\section{Joinery}

The hall of the selected joinery (MIRROR CZ, spol. s r.o., branch Holubice), where we performed measurements of nanoparticles during processing of exotic woods, had the area of 700 $\mathrm{m}^{2}$ and the volume of $3500 \mathrm{~m}^{3}$. The hall and the individual technology elements were connected to a filtering extraction system made by Cipres Filtr with the power output $37 \mathrm{~kW}$, equipped with a box filter Carm situated outside the hall.

Initially, we performed pilot measurement of the quantity of nanoparticles released by technological operations, such as drilling, cutting, milling and grinding on a grinding machine with an abrasive band. As the concentration of nanoparticles measured during the last operation was by two orders of magnitude higher than that at the other operations we focused on that most risky technological operation. The presented experiment was conducted at night on the grinding machine with an abrasive band and it was used for grinding of surfaces of exotic woods present on the Czech market (Massaranduba, Ipé, Garapa, Teak, Bilinga, Jatoba, Bangkirai, Merbau, Faveira) with abrasive paper, using the speed $17 \mathrm{~m} / \mathrm{s}$ and abrasive grain AA 100 .

During wood processing on the grinder we determined the level of wood reduction by grinding (the biggest reduction was found for Garapa, for Merbau it was 3 times lower), we measured distribution of nano- and microparticles, we took samples of sedimented dust for IR analysis, microscopic analysis of shape of the particles and we also used TGA and DSC analyses to determine thermal stability of the dust as a risk factor affecting potential fire risk [22]. We also investigated optically stimulated luminescence and biological activity to E. coli etc. The experiment included an efficiency test of the REFIL 530 respirator - protective equipment for operator of the grinding machine with an abrasive band. One of the reported indicators of efficient protection of the respiratory tract is the FIT factor. It is generally defined as a ratio of the concentration of particles in the surroundings and the number of particles behind the protective barrier. Although the FIT factor expresses the reduction of particles concentration as a result of the respiratory tract protector, a more practical expression is the so-called efficiency of the protective equipment $\mathrm{S}$, indicated in \%.

\subsection{Distribution of nanoparticles in the premises with an abrasive band grinder and the FIT factor}

The results of measurements of distribution of the nanoparticles collected during grinding on the grinder with abrasive band [Figure No. 1, measuring point a)] for certain ground woods are provided in Figure No. 2. Next to them there are diagrams for the same woods with results of measurement of numbers of particles outside and inside the respirator, as determined during specified activities performed by the tested person. The activities were performed for 1 minute each and they included normal breathing, deep breathing, head moving from side to side, head moving up and down, talking, bending down and in the end again normal breathing. 

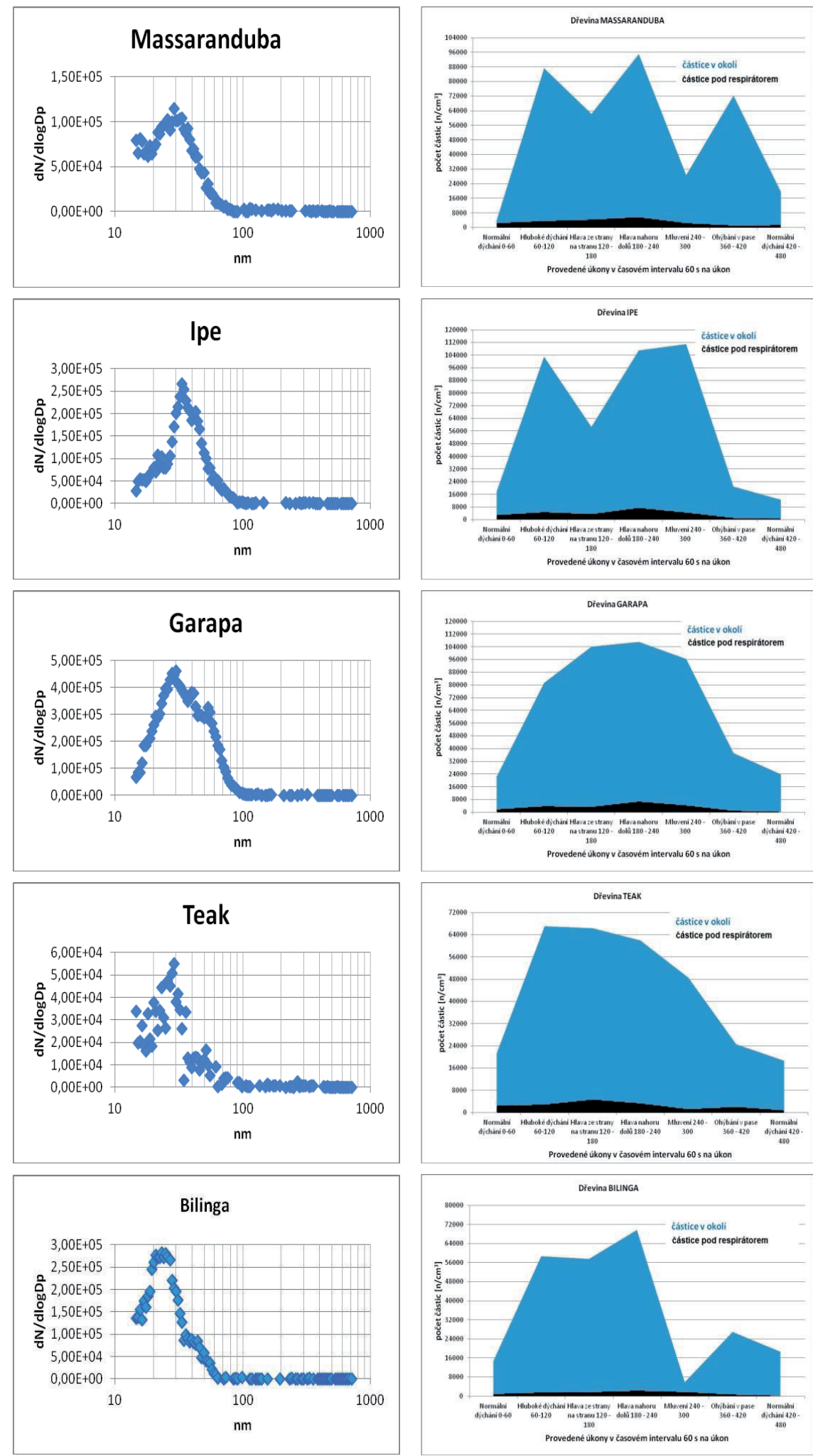

Fig. 2: Distribution of wood nanoparticles and numbers of particles outside and inside the respirator. 
(dřevina $=$ wood; částice $v$ okoli $=$ particles outside the respirator, částice pod respirátorem $=$ particles inside the respirator

Počet částic $=$ Number of particles

Provedené úkony $v$ časovém interval 60 s na úkon = performed activities lasting 60 seconds each

Normální dýchání = normal breathing, Hluboké dýchání = deep breathing, Hava ze strany na stranu = Head moving from side to side, Hlava nahoru dolü = Head moving up and down, Mluveni = Talking

Ohýbání $v$ pase $=$ Bending down, Normálni dýchání = normal breathing)

The measured values were used to calculate the FIT factors and efficiency of the protective equipment - S (see tab. No. 2).

Table 2: Individual FIT factors and overall effectiveness of the protective respirator.

Defined activity $\quad$ FIT factor

\begin{tabular}{|l|l|l|l|l|l|}
\hline & Massaranduba & Ipé & Garapa & Teak & Bilinga \\
\hline Normal breathing & 19 & 21 & 30 & 18 & 39 \\
\hline Deep breathing & 21 & 17 & 25 & 23 & 37 \\
\hline Head moving from side to side & 18 & 23 & 32 & 13 & 38 \\
\hline Head moving up and down & 11 & 14 & 15 & 16 & 27 \\
\hline Talking & 18 & 16 & 18 & 30 & 26 \\
\hline Bending down & 46 & 16 & 36 & 10 & 31 \\
\hline Normal breathing & 16 & 22 & 134 & 25 & 113 \\
\hline Overall FIT factor & 18 & 17 & 26 & 16 & 35 \\
\hline Respirator efficiency S & $94.4 \%$ & $94.1 \%$ & $96.2 \%$ & $93.8 \%$ & $97.1 \%$ \\
\hline
\end{tabular}

The diagrams showing quantities of particles outside and inside the respirator (see Figure2) and values in the table No. 2 indicate a certain correlation between values of the FIT factor and the activity performed by the tested person. The lowest factor, i.e. the lowest efficiency, has been found for the movement of the head up and down and for talking. The explanation may be the untight edge of the respirator on the face (e.g. caused by grimaces when the person is talking). On the contrary, the highest factor was found for normal breathing without other movements.

It is also interesting to mention how the concentrations of particles of individual woods change in time in the course of grinding. For Garapa and Teak woods there was no pulsating character of concentrations as it was the case with the other woods (e.g. Massaranduba wood demonstrated a kind of regular pulsating concentrations).

\section{Steelworks}

The basic objective of steelmaking in the oxygen convertor used in EVRAZ Vítkovice Steel, a.s. is to remove undesired contamination from the raw iron melt by oxidization. The oxidization process is discontinuous and it may be divided into the following steps: a) preparation and storage of the metal melt, b) pre-treatment of the metal melt, c) oxidization in the oxygen convertor, d) secondary metallurgy, e) casting. Before experimental measurements we tried to identify locations with potentially increased levels of emissions but we also had to consider safety of the measuring workers and sensitivity of the employed instrumentation to the environment in some measuring points, e.g. high temperature, explosive environment etc.

The compromise locations selected as measuring points for the distribution of nanoparticles the slab casting and the scarfing machine. The measurement of weight capture of aerosol particles with personal cascade impactors was performed in the convertor hall of the steelworks at various distances from the convertor door and on a platform above recasting of liquid iron.

\subsection{Distribution of nanoparticles in locations of slab con- tinual casting and at the scarfing machine}

6 spectrums were measured in the range from 14 to $736 \mathrm{~nm}$ and the average values are shown in Figure No. 3 and Figure No. 4. 


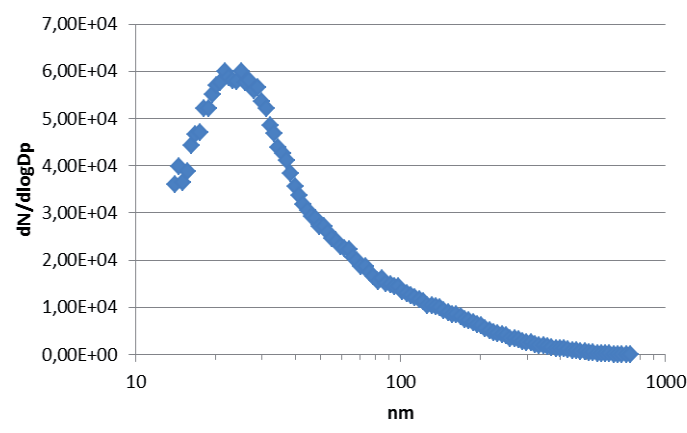

Fig. 3: Distribution of aerosol particles of slab continual casting.

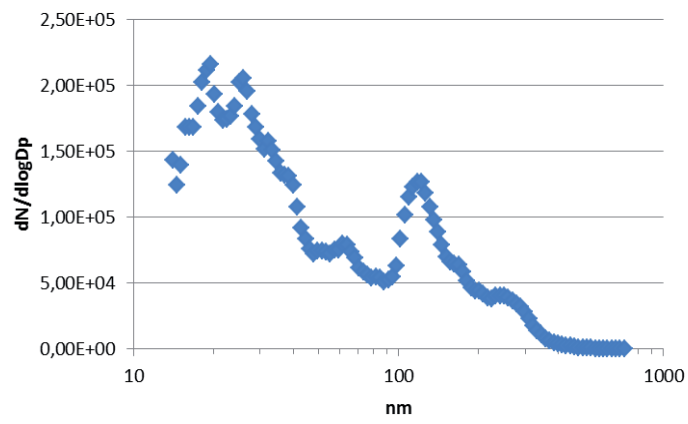

Fig. 4: Distribution of aerosol particles at the scarfing machine.

The main peaks around $20 \mathrm{~nm}$ are mutually corresponding but higher concentrations of nanoparticles are found in the proximity of the scarfing machine, while there are also particles with the diameter around $120 \mathrm{~nm}$. Also the overall concentration of particles in the nano area is higher by one order and their weight is $5 \times$ higher $\left(166 \mu \mathrm{g} / \mathrm{m}^{3} \mathrm{com}\right.$ pared to $28 \mu \mathrm{g} / \mathrm{m}^{3}$ ).

\section{Steel Rolling Plant}

The steel rolling plant is also the property of EVRAZ Vítkovice Steel a.s. After adjusting their dimensions the steel slabs weighted and moved into the pusher furnace.

The rolling mill has two pusher furnaces with the capacities of 75 and 90 t.hour $^{-1}$. The pusher furnaces have door openings and pushing equipment. The furnace has a pre-heating zone, heating zone and equalizing zone. The furnace is heated with natural or converter gas using burners. Combustion products are removed in the direction opposite to the slab movement. After opening the door of the pusher furnace, as shown in Figure No. 1d), the preheated slab (ca. $1000-1200^{\circ} \mathrm{C}$ ) is transported on a rolling mill train to the rolling stand - Figure No. 1e). Before that iron scale is removed by water beam sprayed by hydraulic adjustable jets (15-25MPa, flow rate $54\left(1 . \mathrm{s}^{-1}\right)$. Further, the so-called secondary descaling is performed on rolled out pieces, on the bottom and upper surfaces. The rolling train also includes a thickness gauge, shears for hot transverse cutting, leveling machine and it is terminated with two cooling beds.

\subsection{Distribution of nanoparticles in the premises of the steel rolling train and pusher furnace}

The measurements of quantities and distribution of nanoparticles were performed at the steel rolling train, one $15 \mathrm{~m}$ from the rolling stand and the other at the pusher furnace, $8 \mathrm{~m}$ from the furnace door.

The individual spectrums obtained from the measurements (the device counts the particles for 3 minutes and for 2 minutes it evaluates the data) made it possible for us to determine the total concentration graphically and to determine the geometric diameter of the particles (geom).

A comparison of diagrams in Figure No. 5 - 6 shows that the number of measured nanoparticles is by one order higher at the pusher furnaces than at the rolling train. On the contrary, the geometric diameter of the particles at the train is slightly smaller than at the furnaces. During the measuring campaign at the pusher furnaces the measured values of quantities of nanoparticles had a pulsating character with the difference up to 200 thousand particles. The cause was primarily the open doors of the furnaces (see Figure No. 6, spectrum No. 1) because during the measuring campaign the pre-heated slab was moving out. The measured quantities of particles at the rolling train were fairly leveled - see Figure No. 5, although preheated slabs passed 3 times by the measuring point during the campaign.

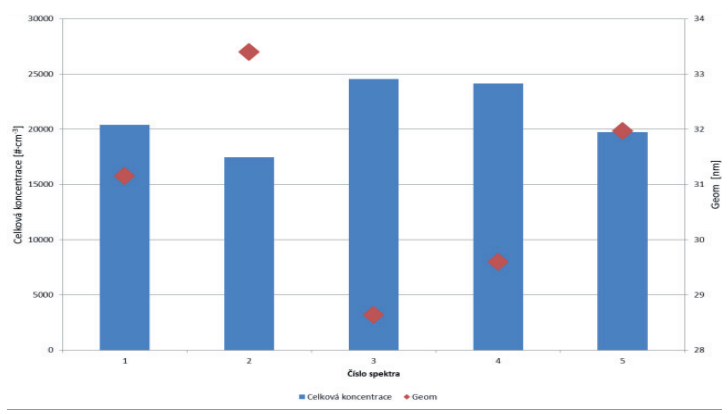

Fig. 5: Total concentration of particles, including geometric diameter of particles at the steel rolling train. (Celková koncentrace $=$ total concentration, čislo spectra = spectrum number). 


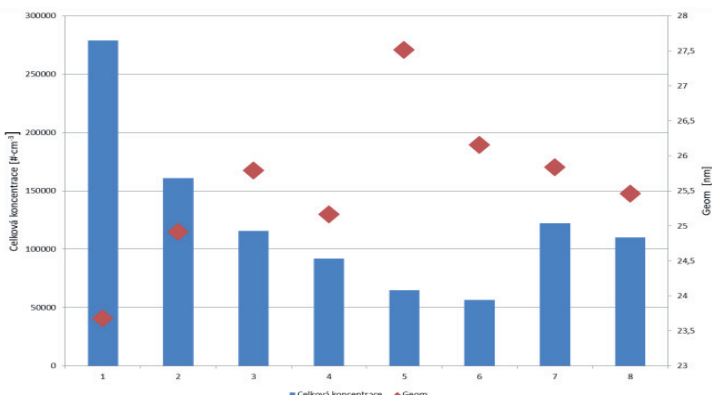

Fig. 6: Total concentration of particles, including geometric diameters of particles at the pusher furnace. (Celková koncentrace = total concentration, čislo spektra = spectrum number).

A comparison of averaged values of distribution of nanoparticles measured at the steel rolling stand and at the pusher furnace is provided in a graphic form in Figure No. 7. The diagram indicates an exponential growth of the number of nanoparticles of small diameter at the pusher furnace.

At the same time, effectiveness of the REFIL 530

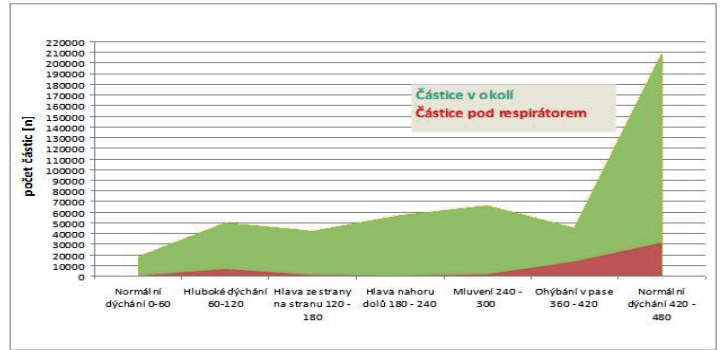

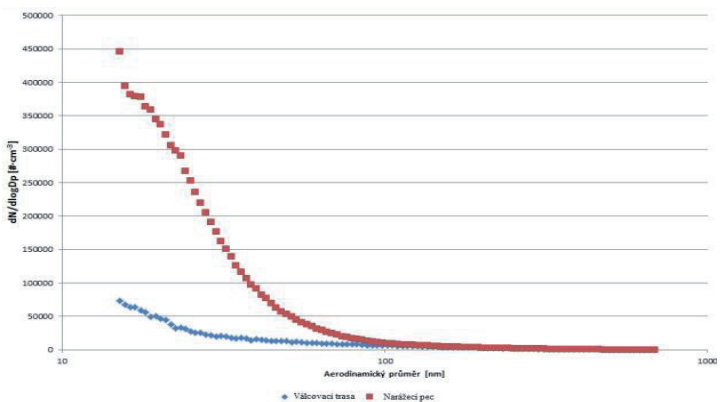

Fig. 7: Comparison of the distribution of nanoparticles at the rolling stand and at the pusher furnace.

(Aerodynamický prüměr = aerodynamic diameter, Válcovací trasa = rolling train, Narážecí pec $=$ pusher furnace)

FFP 2 respirator was tested in the measured premises with the result 90.9 - 99.1\%. As an example we present the measured values of aerosol nanoparticles outside and inside the respirator in a graphic form with calculated values of the FIT factor and effectiveness at the rolling train (see Figure No. 8).

\begin{tabular}{|c|c|c|}
\hline Definované úkony & $\begin{array}{l}\text { FIT } \\
\text { faktor }\end{array}$ & $\begin{array}{l}\text { Účinnost } \\
\text { respirátoru }\end{array}$ \\
\hline Normální dýchání & 67 & 98,5 \\
\hline Hluboké dýchánî & * & 83,3 \\
\hline Pohyb hlavy ze strany na stranu & 46 & 97,6 \\
\hline Pohyb hlavy nahoru a dolů & 72 & 98,6 \\
\hline Mluvení & 37 & 97,3 \\
\hline Ohýbání v pase & 9 & 88,8 \\
\hline Normální dýchání & 6 & 83,3 \\
\hline Celkový FIT FAKT OR & 14 & \\
\hline Účinnost respirátoru $S$ & & $92,9 \%$ \\
\hline
\end{tabular}

Fig. 8: Diagram showing numbers of particles outside and inside the respirator at the rolling train $8 \mathrm{~m}$ from the rolling stand, calculated FIT factor and respirator efficiency.

Počet částic $=$ Number of particles, Částice vokolí $=$ particles outside the respirator, Částice pod respirátorem $=$ particles inside the respirator Definované úkony $=$ defined activities, FIT factor = FIT factor, Účinnost respirátoru $=$ Respirator efficiency, Normální dýchání $=$ normal breathing, Hluboké dýchání = deep breathing, Hlava ze strany na stranu = Head moving from side to side, Hlava nahoru dolü = Head moving up and down, Mluveni $=$ Talking

Ohýbánív pase = Bending down, Normální dýchání = normal breathing

Celkový FIT FAKTOR = Overall FIT factor, Účinnost respirátoru S = Respirator effectiveness S

*Activities accompanied by escape of steam from the rolling machine towards the measuring point.

\section{Deep Mining of Uranium Ore}

The last active mine for uranium ore in the Czech Republic and Europe is in Rožná in the BohemianMoravian Highlands. Since 1992 it has been a part of the state enterprise DIAMO.

The rock complex on the territory with deposits consists mainly of biotitic and amphibol-biotitic paragneisses that are differently migmatized and they enclose zones of amphibolite, erlan intercalations, crystalline limestones, quartzite, serpentinite and pyroxenite.

Uranium ore mineralization occurs in three types: zonal, venal and metasomatic. The uranium ore mineralization is of hydrothermal origin and it is localized in tectonic disturbances. The main ore minerals are uranite (UO2) and coffinite (UO2)SiO2. There is also uranophane and metacolloid hydrated uranium oxides - uranium blacks (often in association with pyrite and markasite), as well as autunite, torbernite, curite, opals containing uranium and other uranium 
minerals [23 - 25]. The average metal content of the deposit is $0.08-0.15 \%$.

The non-uranium mineralization is represented by graphite, carbonates, quartz, baryte, oxides, selenides, sulfides, zeolites.

The main heavy metals contained in the minerals are $\mathrm{Pb}, \mathrm{Zn}, \mathrm{Mn}, \mathrm{Cd}, \mathrm{As}$.

6.1. Measurements of quantities of aerosol nanoparticles and efficiency of various respirator types

Measuring of quantities of aerosol nano- a mi- cro- particles was conducted on the 21st floor, $1050 \mathrm{~m}$ under the ground. The measurements were performed during the morning shift, 2 hours after a blast (March 2013). Scraped loose material was transported into an ore chute and mine trucks were loaded discontinuously (see Figure No. 1f)). The measurements were conducted at the same location, including determination of efficiency of three types of respirators. The results are provided in table 3.

Table 3: Average values of the measured aerosol nanoparticles, FIT factor and efficiency of respirators.

\begin{tabular}{|l|l|l|l|l|}
\hline Respirator type & $\begin{array}{l}\text { Average concentration } \\
\text { of aerosol outside the } \\
\left.\text { respirator [n.cm }{ }^{-3}\right]\end{array}$ & $\begin{array}{l}\text { Average concentration } \\
\text { of aerosol inside the } \\
\left.\text { respirator [n.cm }{ }^{-3}\right]\end{array}$ & 5.4 & 81 \\
\hline $\begin{array}{l}\text { SERGE } \\
\text { FPP2U }\end{array}$ & 256428 & 47485 & 11.8 & 89 \\
\hline $\begin{array}{l}\text { REFIL 530 } \\
\text { FFP2 }\end{array}$ & 255142 & 22802 & 917.5 & 99,99 \\
\hline $\begin{array}{l}\text { Triosyn T-5000 V, } \\
\text { FFP-3 }\end{array}$ & 154142 & 917 & 40.5 & 97 \\
\hline $\begin{array}{l}\text { REFIL 530 } \\
\text { FFP2 used }\end{array}$ & 361428 & 8910 & & 97 \\
\hline
\end{tabular}

a) averaged values measured during the experiment while the tested person wearing a respirator was performing specified tasks (each for 1 minute, normal breathing, deep breathing, head moving from side to side, talking, bending down, normal breathing).

The concentration of nano- and microparticles achieved in the proximity of the tested person was higher than e.g. in the course of grinding of exotic woods with a grinder with abrasive band or during casting and rolling of slabs in the steel works.

The table 3 indicates that the least effective respirator was SERGE while Triosyn T 5000V was positively the best from the viewpoint of interception of particles and thus protection of employees. In respect to the found residual concentration inside the respirator we have also considered the option of desorption from the respiratory tract of the tested person who was a smoker.

The increased effectiveness of the REFIN respirator (used for 2 hours in the premises) can be explained by its partial clogging but it was at the expense of breathing comfort which was at the edge of tolerability. We dare conclude that the respirator cannot be used for the entire shift.

\section{Interception of Aerosol Particles on Impactor Filters in the Monitored Dust Producing}

\section{Operations}

As mentioned in the introductory section, one of the risk factors of inhalation of micro- and nanoparticles, apart from concentration, chemical composition and size of the particles, is their surface. The surface influences fixing of the particles in respiratory organs. A textbook example is the difference in toxicity of Saharan sand (round particles - worn by years of erosion) and glass sand (sharp particles risk of silicosis). An impactor was used in the course of monitored technological operations to collect samples of intercepted particles. Subsequently, the particles were investigated with electron microscopy. Examples of the images are in shown Figure No. 9 - sharp particles of organic origin, Figure No. 10 - irregular shape of iron and carbon particles, Figure No. 11 - spherical particles or partly oxidized iron, Figure No. 12 - mixture of irregular metal particles of zinc and iron in form of pyrite in the environment of aluminum silicate and magnesium silicate, Figure No. 13 - uranium cation identified with a cross in a mixture of irregular shapes. 
Acta Mechanica Slovaca

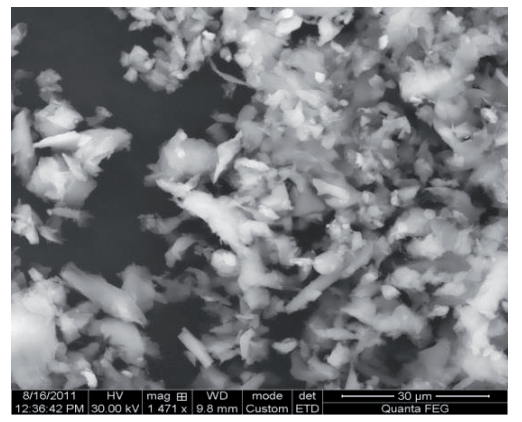

Fig. 9: Electron microscope image of intercepted nano- and microparticles of Massaranduba woods during grinding - joinery.

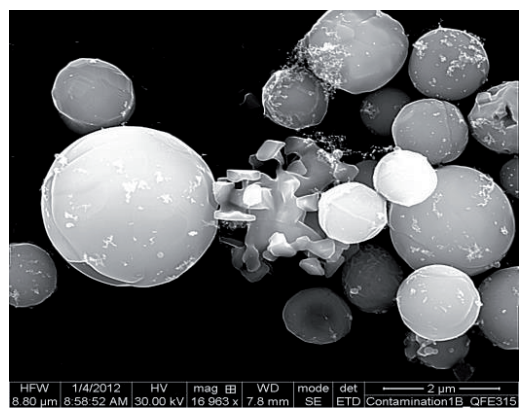

Sorting limit $(2,5 \mu \mathrm{m})$

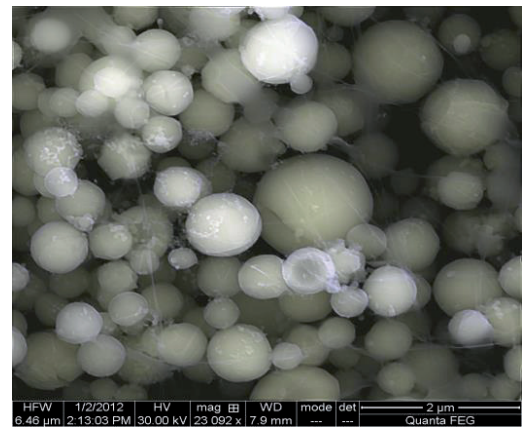

Sorting limit $(0,5 \mu \mathrm{m})$

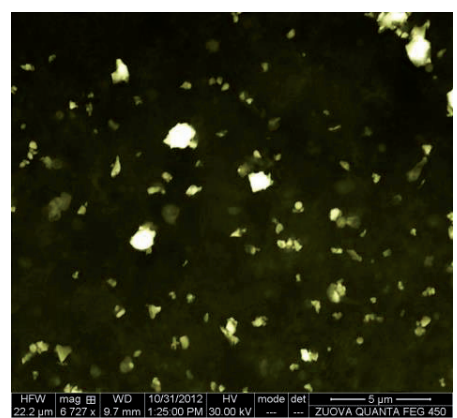

Fig. 10: Electron microscope image of nano- and a microparticles at the pusher furnace.

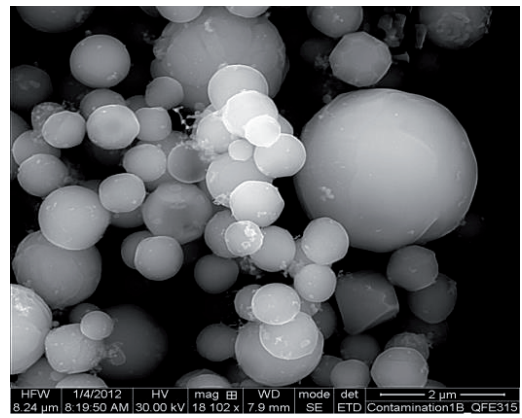

Sorting limit $(1 \mu \mathrm{m})$

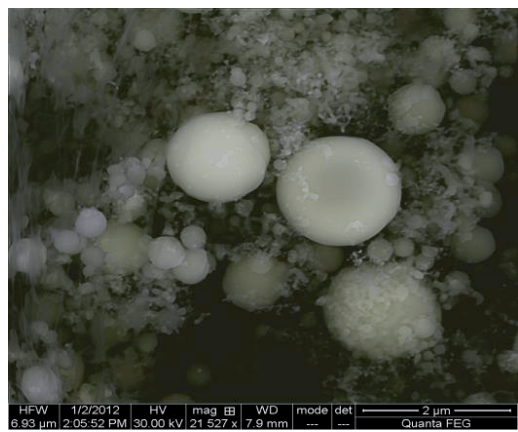

Sorting limit $(0,25 \mu \mathrm{m})$

Fig. 11: Electron microscope images of intercepted of nano- and microparticles from steelworks during raw iron casting.
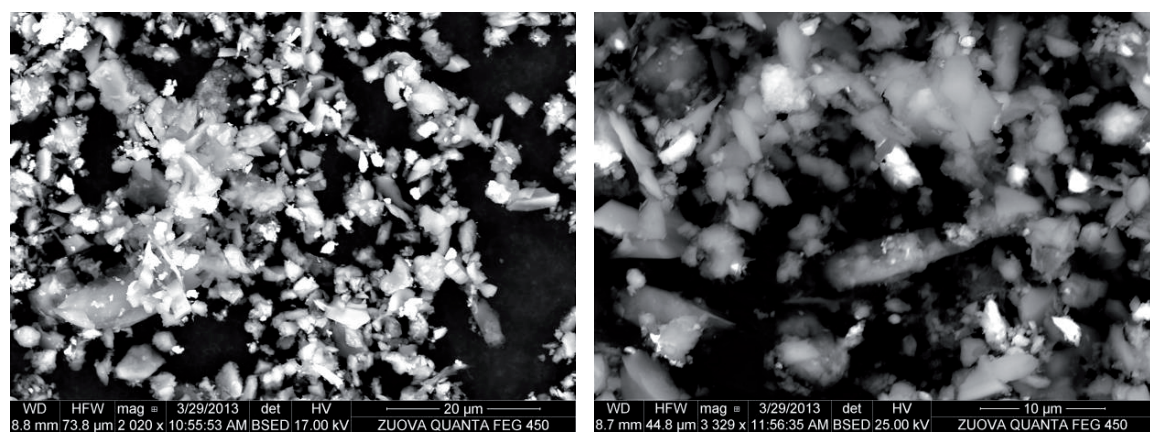

Fig. 12: Electron microscope images of nano- and microparticles from the uranium ore mine.. 

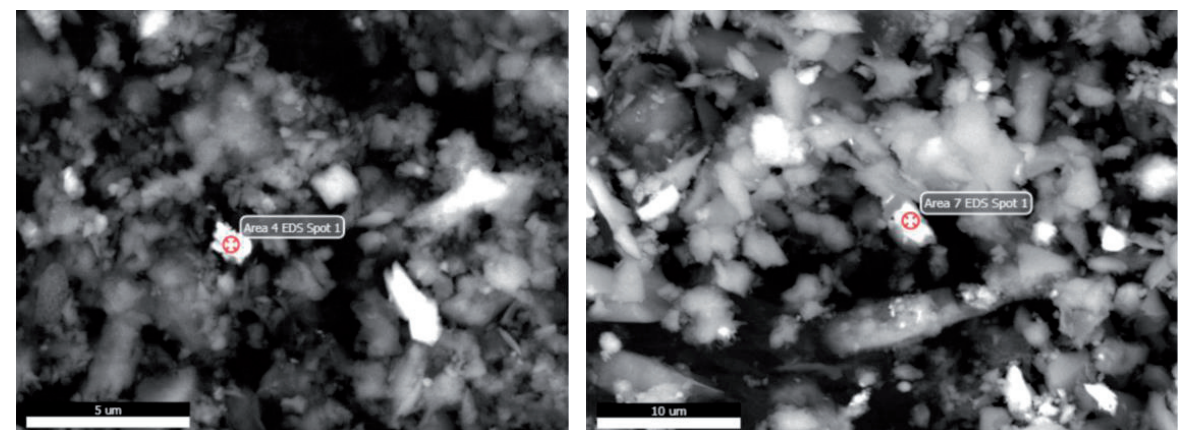

Fig. 13: Electron microscope images from uranium ore mine environment with identification of uranyl (cross)..

\section{Conclusions}

Inhaling of aerosol micro- and nanoparticles leads to their deposition in the human respiratory tract and in many cases it is assumed that they are transported into other terminal organs. Numerous epidemiological studies have determined their negative effect on respiratory and cardiovascular systems in sensitive members of the population [20].

In respect to toxicity, in many cases we face a question of the roles of concentration, chemical composition and shape of the particles. Chemical composition of wood is extremely varied and unstable [26]. Apart from dominant components, such as cellulose, hemicellulose and lignin, it contains many substances from the categories of terpenoids, phenols, tannins, quinones, stilbenes, proteins, alkaloids etc., which may feature biological activity, both favorable and unfavorable. In respect to the shape of the particles, sharp particles that we identified during grinding of some exotic woods (e.g. Massaranduba, Jatoba) seem to be the most risky. They may have a similar effect on the organism as asbestos.

Round shapes of nanoparticles of partly oxidized iron that we identified at the recasting of raw iron probably reduce their toxicity, simplify transport from alveoli by breathing out (if we disregard the role of specific weight).

The appropriate concentration of iron, as an essential element, is important for human health: it is involved in transport of oxygen (hemoglobin, myoglobin) in cellular breathing. If the concentration of iron in the organism exceeds the capacity of transport and spare proteins for iron then it starts depositing in tissue. Increased deposition of iron in tissue causes fibrotization and reduction of functional tissue. The main symptoms are development of liver hemosiderosis and later cirrhosis, diabetes type II, cardiomyopathy, arthritis etc.
A discussion evolved relating to determination of a permissible concentration uranium in drinking water [27]. An analysis which was made as a result of the professional discussion has shown [28 - 32] that the absorbed uranium enters the bloodstream quickly and forms a mobile ion complex of hydrocarbonate and uranyl (UO2 HCO3)+. The complex is quickly transported by blood, particularly to kidneys and bones. It damages epithelium of the kidney proximal tubuli, disturbs their resorptive function and it has a cytotoxic effect (nephrotoxicity). In the skeleton the uranyl ion replaces calcium in the hydroapatite complex of the crystalline bone grid. Moreover, it has been demonstrated that it can penetrate the placental barrier. Genotoxic and carcinogenic effects have not been demonstrated and developmental toxicity was demonstrated in higher doses.

In metallurgical operations and in ore mines it is necessary to take into account the presence of heavy metals. The toxicity is caused by bonding of their electrophilic cations to $-\mathrm{SH},-\mathrm{COOH},-\mathrm{NH} 2$ groups, i.e. biomolecular groups (proteins), since they change their structure, function and operate as enzymatic poisons. They also inhibit cell division. They catalyze reactions that produce free radicals oxidative stress [33]. Very dangerous is the ability of metals to accumulate in various body tissues. Another potential process is the so-called bio-methylation, i.e. transformation of the inorganic form of the metals into the organic form, which is mostly associated with an increase of toxicity and which occurs in the digestive tract of vertebrate. Another factor affecting their toxicity is the presence of several metals and their ions which may have a synergic effect on the toxicity. The so-called metal fume fever is a well known disease explained by formation of complexes of e.g. zinc and nickel with proteins in alveoli 
of the lungs or in plasma and they subsequently operate as foreign proteins and make the organism to respond.

\section{Acknowledgement}

Brádka S., Topinková H., Otáhal P., Weisheitlová M. Witkovská V.

\section{References}

[1] David, A.; Wagner, G.R. (1998). Respiratory system. In: Encyclopaedia of occupational health and safety, 4th edition. Stellman JM, ed. Geneva: International Labour Office, pp.101-107.

[2] Rozman, K.K.; Klaassen, C.D. (2001). Absorption, distribution and excretion of toxicants. In: Casarett and Doull's Toxicology: the Basic Science of Poisons, sixth edition. Klaassen, C.D. ed. New York: McGraw-Hill, pp.105-132.

[3] Winder, C. (2004). Toxicology of gases, vapors and particulates. In: Occupational Toxicology. Second edition. Winder C, Stacey NH, eds. Boca Raton: CRC Press, pp.399-424.

[4] Lundborg, M.; Johard, U.; Lástbom, L.; Gerde, P.; Camner, P. (2001). Human alveolar macrophage phagocytic function is impaired by aggregates of ultrafine carbon particles. Environmental Research, Vol. 86,pp.244-253.

[5] Donaldson, K.; Stone,V.; Tran, C.L.; Kreyling, W.; Borm, P.J. (2004). Nanotoxicology. Occupational and Environmental Medicine, Vol. 61, pp.727-728

[6] Peters, K.; Unger, R.E.; Kirkpatrick, C.J.; Gatti, A.M.; Monari, E. (2004). Effects of nano-scaled particles on endothelial cell function in vitro studies on viability, proliferation and inflammation. Journal of Materials Science Material in Medicine, Vol.15, pp.321-325.

[7] Renwick, L.C.; Brown, D.; Clouter, A.; Donaldson, K. (2004). Increased inflammation and altered macrophage chemotactic responses caused by two ultrafine particle types. Occupational and Environmental Medicine, Vol. 61,pp.442-447.

[8] Borm, P.; Robbins, J.A.; Haubold, D.; Kuhlbusch, S.; Fissan, X.; Donaldson, H.; Schins, K.R.; Stone,V.; Kreyling, W.; Lademann, J.; Krutmann, J.; Warheit, D.; Oberdorster, E. (2006). The potential risks of nanomarerials: a review carried out for ECETOC. Particle and Fibre Toxicology, Vol. 3,pp1-35.

[9] Brunner, T.J.; Wick, P.; Manser, P.; Spohn, P.; Grass, R.N.; Limbách, L.K.; Bruinink, A.; Stark, W.J. (2006). In vitro cytotoxicity of oxide nanopartícles: comparison to asbestos, silica, and the effect of particle solubility. Environmental Science Technology, Vol. 40,pp.4374-4381.

[10] Gojova, A.; Guo, B.; Kota, R.S.; Rutledge, J.C.; Kennedy, I.M.; Barakat, A.I. (2007). Induction of Inflammation in vascular endothelial cells by metal oxide nanoparticles: effect of particle composition. Environmental Health Perspectives, Vol. 115, pp.403-409.

[11] Dechsakulthorn, F.; Hayes, A.; Bakand, S.; Joeng, L.; Winder, C. (2008). In vitro cytotoxicity of selected nanopartides using human skin fibroblasts. AATEX Journal, Vol. 14,pp.397400.

[12] Nel, A.; Xia, T.; Mádler, L.; Li, N. (2006). Toxic potential of materials at the nanolevel. Science, Vol. 311,pp.622-627.

[13] Nel, A. E.; Mädler, L.; Velegol, D.; Xia, T.; Hoek, E. M. V.; Somasundaran, P.; Klaessig, F.; Castranova, V.; Thompson, M. (2009).Uderstanding biophysicochemical interactions at the nano-bio interface, Nature Materiále, Vol. 8, pp. 543557.

[14] Bakand, S.; Hayes, A.; Dechsakuthorn, F. (2012) Nanoparticles: a review of particle toxikology following inhalation exposure, Inhalation Toxicology, Vol.24, pp.125-135.

[15] Medinsky, M.A.; Bond, J.A. (2001). Sites and mechanisms for uptake of gases and vapors in the respiratory tract. Toxicology, Vol. 160,pp.165-172.

[16] Dockery, D.W.; Pope, C.A.; Xu, X.; Spengler, J.D.; Ware, J.H.; Fay, M.E.; Ferris, B.G.; Speizer, F.E. (1993). An association between air pollution and mortality in six U.S. cities. The New England Journal of Medicine, Vol. 329, pp.1753-1759.

[17] Chauhan, A.J.; Johnston, S.L. (2003). Air pollution and infection in respiratory illness. British Medical Bulletin, Vol. 68, pp.95-112.

[18] Kan, H.; London, S.J.; Chen, G.; Zhang, Y.; Song, G.; Zhao, N.; Jiang, L.; Chen, B. (2008). Season, sex, age, and education as modifiers of the effects of outdoor air pollution on daily mortality in Shanghai, China: The Public Health and Air Pollution in Asia (PAPÁ) Study. Environmental Health Perspectives, Vol. 116,pp.1183-1188.

[19] Rückerl, R.; Schneider, A.; Breitner, S.; Cyrys, J.; Peters, A. (2011). Health effects of particulate air pollution: A review of epidemiological evidence. Inhalation Toxicology, Vol. 23, pp.555-592.

[20] Nohavica, D. (2009). Respirační a kardiovaskulární problémy související s nanočásticemi. NANOCON 2009, Rožnov pod Radhoštem, sborník abstraktů pp. 76, ISBN 978-8087294-12-3

[21] Klouda, K.; Brádka, St.; Otáhal, P. (2012). Experiences with Antropogenic Aerosol Spread in the Environment, Chapter 17, Atmospheric Aerosols-Regional CharacteristicsChemistry and Physics, Intechopen.com, 2012, ISBN: 978953-51-0728-6

[22] Klouda, K.; Matheisová, H. (2012). Tepelná stabilita sedimentovaných prachů z vybraných exotických dřev. Požární ochrana 2012, Sborník pp.113 - 116, ISBN 978-807385-115-6.

[23] Seque, D. M. (2010), Mineralogická charakteristika nového 
sulfidického zrudnění z uranového dolu Rožná, bakalářská práce, Masarykova univerzita,Brno, pp.28.

[24] Hajek, A. (2007), 50. vyroči zahajeni těžby na ložisku Rožná 1957-2007, Diamo, pp..60.

[25] Dobiášová, H. (1987), Uranové Doly, Dolní Rožínka 19571987. Brno, pp. 80.

[26] Jankovský, M.; Lachman, J.; Staszková, L. (1999), Chemie dřeva. Česká zemědělská univerzita, Praha 1999, ISBN 80213-0559-2.

[27] Kožíšek, F.; Jeligová, H.; Havel, B. (2013), Stanovisko Státního zdravotního ústavu - Národního referenčního centra pro pitnou vodu k limitní hodnotě uranu v pitné vodě ze dne 12. 3. 2013

[28] Klusáková, L. (2010), Těžba uranu v prostoru Dolní Rožínky a zdravotní rizika horníků, diplomová práce, Masarykova univerzita Brno, pp. 41.

[29] Chronic Ingestion of Uranium in Drinking Water: A Study of Kidney Bioeffects in Humans, Toxicological Sciences 1998, Vol. 43, pp. 68-77.

[30] Uran v pitné vodě - hodnocení rizika z hlediska chemické toxicity, Státní zdravotní ústav Praha, (2001), pp. 10.

[31] Hanusková, V. (2008), Výskyt uranu v pitné vodě Jihomoravského kraje a jeho stanovení, diplomová práce, Vysoké učení technické v Brně, pp. 44.

[32] Jeligová, H. (2009), Uran v pitné vodě, Kinetika uranu v organismu, Toxikologická informace SZU Praha.

[33] Kafka, Z.; Punčochářová, J. (2002). Těžké kovy v prírodě a jejich toxicita. Chemické listy, Vol.96, pp. 611-617. 